\title{
Strategies of chemical management for weed control in cassava
}

\author{
Neumárcio Vilanova da Costa ${ }^{1}$, (1) Anderson Marcel Gibbert ${ }^{*} \mathbb{1}$, Silvio Douglas Ferreira ${ }^{1} \mathbb{D}$, \\ Hiago Canavessi ${ }^{1} \mathbb{D}$, Adriana Cologni Salvalaggio ${ }^{1} \mathbb{C}$
}

10.1590/0034-737X202067030010

\begin{abstract}
The use of strategies such as sequential applications and mixtures may increase the control spectrum and the residual effect of chemical control of weed in the cassava crop. Thus, the objective was to evaluate the selectivity and efficacy of sequential applications and tank mixture of herbicides in the control of weed in the cassava crop cultivar 'Baianinha'. The experimental design was of randomized blocks, with eleven treatments and four replicates. The treatments consisted in: harrowed control, control without harrow, clomazone, mesotrione, S-metolachlor, clomazone+S-metolachlor, mesotrione+S-metolachlor, clomazone+mesotrione, sulfentrazone/clomazone, clomazone/[mesotrione+S-metolachlor], S-metolachlor/[mesotrione+clomazone]. The doses used for clomazone, mesotrione, sulfentrazone and S-metolachlor in the single applications, in sequence and in tank mixture were of $1.25,0.24 ; 0.6$ and $1.92 \mathrm{~kg} \mathrm{ha}^{-1}$, respectively. The first application of the sequential treatments occurred 50 days after planting (DAP) and the second at 92 DAP. The applications of mesotrione, mesotrione+clomazone and mesotrione+S-metolachlor, were carried late, at $92 \mathrm{DAP}$. Based on the data obtained, it is concluded that the mixture mesotrione+S-metolachlor and the sequential application of clomazone/ [mesotrione+S-metolachlor] were selective to cassava 'Baianinha' and efficient in the weed control (over $80 \%$ up to 148 days after planting).
\end{abstract}

Keywords: Manihot esculenta; weed management; chemical control; herbicides; tank mixture.

\section{INTRODUCTION}

Cassava (Manihot esculenta Crantz) stands out in Brazil due to its economic and social importance once it is possible to be cultivated in all regions. The area destined to cassava crops in the country in 2016 was of about 1,5 million hectares with a production of 23,71 million tons of roots, being the states Pará, Paraná and Bahia the greatest producers (IBGE, 2017).

Despite its rusticity and high adaptability, the cassava crop can have its production reduced due to the presence of weed. However, the crop cannot have weed for about 18 to 100 days after planting which make it necessary the adoption of any control measure during this period, on the contrary the losses in productivity caused by the competition between weed and the crop can reach up to 100\% (Biffe et al., 2010a).
To avoid damages caused by weed competition, it is necessary the use of control methods. In the cassava crops, the chemical control is widely used due to the high operating income, crop selectivity and high efficiency in the control of weed, what contrasts the low hand work availability in farms to perform manual weeding (Silveira $e t$ al., 2013). However, there are few herbicides registered for cassava, a reflection of the minimal impact of this crop in the national economic scenery when compared to other crops such as soybean, maize and sugarcane (Silva et al., 2009).

In Brazil, only the herbicides ametrine, clethodim, clomazone, isoxaflutole, metribuzin, dimethenamid-P, Smetolachlor, flumioxazin, fluasifop-p-butylic and the commercial mixture of ametryn+clomazone are registered for the cassava crop, most of them pre-emergent and monocotyledon herbicides (Adapar, 2018; Agrofit, 2018).

\footnotetext{
Submitted on February $19^{\text {th }}, 2019$ and accepted on April 14 $4^{\text {th }}, 2020$.

${ }^{1}$ Universidade Estadual do Oeste do Paraná, Centro de Ciências Agrárias, Marechal Cândido Rondon, Paraná, Brazil. neumarciovc@hotmail.com; anderson_gibbert@hotmail.com; agrosilvio@outlook.com; canavessi1996@hotmail.com; adriana.salvalaggio@outlook.com

*Corresponding author: anderson_gibbert@hotmail.com
}

Rev. Ceres, Viçosa, v. 67, n.3, p. 240-246, may/jun, 2020 
However, due to the reduced number of herbicides registered, the adoption of chemical management strategies of weed, as an example the sequential application of isolated or mixed herbicides, may contribute to enlarge control spectrum, improving the residual effect, besides the different action mechanisms, in a way to avoid the selection of resistant weed biotypes (Beckie \& Harker, 2017). As well as Zobiole et al. (2018), which evaluated the association between halauxifen-methyl with other herbicides in the control of Coniza sumatrenis and obtained satisfactory results, with highlight to glyphosate+halauxifenmethyl+diclosulam $\left(1,440+6.32+31.87 \mathrm{~g}\right.$ a.i. ha $\left.{ }^{-1}\right)$, which allows the implementation of a new tool in the management of this weed which is hard to control.

Though, it is believed that the use of strategies of herbicides application pre and post-emergent in a sequential way and in tank mixture is dependent of selective and efficient products in the weed control in the cassava crop. Thus, the objective was to evaluate the selectivity and efficacy of sequential applications and tank mixture of herbicides in the control of weed in the cassava crop cultivar 'Baianinha'.

\section{MATERIAL AND METHODS}

The experiment was conducted under field conditions in the agricultural year of 2016/2017. The experimental design used was of random blocks with 11 treatments and four replications, as described in Table 1.

The cassava 'Baianinha' was planted in July 2016, with the aid of a planter 'Planti Center Bazuca' of two lines, in a spacing of $0.9 \times 0.7 \mathrm{~m}$, being the cuttings placed $10 \mathrm{~cm}$ deep. The parcels constituted of 4 lines of $5 \mathrm{~m}$ long. The crop system adopted was conventional with one plowing followed by two harrowing.

For the herbicides application was used a backpack sprayer pressurized with $\mathrm{CO}_{2}$ at $2.6 \mathrm{kgf} \mathrm{cm}^{-2}$, with a spray lance with capacity to four jet spray nozzles (model Mag- no Jet 11002 AD) distanced apart by $0.5 \mathrm{~m}$, providing a flow rate of $200 \mathrm{~L} \mathrm{ha}^{-1}$.

After planting, the climatic conditions were not favorable for the applications so, because of it, the first herbicide application occurred at 50 days after planting, in humid soil (Figure 1). The weather conditions, such as temperature, moisture and wind speed during the applications were of $20.5^{\circ} \mathrm{C}, 59 \%$ and $1.4 \mathrm{~m} \mathrm{~s}^{-1}$, respectively.

The sequential herbicide application occurred at 92 DAP (42 days after the first application), in dry soil, when the cassava plants had 15 leaves. In the same period were applied the late herbicides (clomazone, clomazone+mesotrione and clomazone+S-metolachlor). The conditions of temperature, moisture and wind speed were of $29^{\circ} \mathrm{C}, 50 \%$ and $1.2 \mathrm{~m} \mathrm{~s}^{-1}$ respectively. The weed development stage at application point was of 2 to 4 tillers for monocotyledon and 8 to 12 pairs of leaves to dicotyledon.

The intoxication of cassava plants and weed control were evaluated at 28, 35, 42, 49, 63, 70, 77 and $981^{\text {st }}$ application first application (DA1A), and at 7, 21, 28, 35 and 56 days after the second application (DA2A). For treatments clomazone, clomazone+mesotrione and clomazone+S-metolachlor, the evaluations occurred at 7 , 21, 28, 35 and 56 days after the late application (DAPL).

The intoxication notes of cassava plants ant the weed control were attributed with basis in the percentage scale proposed by the 'Sociedade Brasileira de Ciência de Plantas Daninhas' (SBCPD, 1995), in which 0 (zero) corresponded to no injury showed by the cassava plants or weed control, and 100 (one hundred) to death of cassava plants or control of weed The characteristics observed in cassava plants for the grades assignment were: growth inhibition, amount and uniformity of injuries o control, the plants regrowth capacity and quantity of dead plants.

Harvest was carried at 12 months after planting, collecting the plants from the two central lines of the parcel, disregarding one plant of each line far end. Roots were

Table 1: Herbicides used in the weed control in cassava 'Baianinha'

\begin{tabular}{lccc}
\hline Treatment & Rate $\left(\mathbf{k g ~ h}^{-\mathbf{1}}\right)$ & Method of Application & DAP \\
\hline Weed control & - & - & - \\
Weed-free control & - & - & - \\
clomazone & 1.25 & Pre emergent & 50 \\
S-metolachlor & 1.92 & Pre emergent & 50 \\
clomazone+S-metolachlor & $1.25+1.92$ & Pre emergent & 50 \\
sulfentrazone/clomazone & $0.60 / 1.25$ & Sequential: Pre/late post emergence & $50 / 92$ \\
clomazone/[mesotrione+S-metolachlor]** & $1.25 / 0.24+1.92$ & Sequential: Pre/late post emergence & $50 / 92$ \\
S-metolachlor/[mesotrione+clomazone]** & $1.92 / 0.24+1.25$ & Sequential: Pre/late post emergence & $50 / 92$ \\
mesotrione** & 0.24 & Late post emergence & 92 \\
mesotrione+S-metolachlor** & $0.24+1.92$ & Late post emergence & 92 \\
mesotrione+clomazone** & $0.24+1.25$ & Late post emergence & 92 \\
\hline
\end{tabular}

$\mathrm{DAP}=$ days after planting. $* * \mathrm{~A}$ mineral oil based adjuvant was added, at a $0.5 \% \mathrm{v} \mathrm{v}^{-1}$ dosage. 
weighted with the aid of a manual digital scale (error $=0.05$ $\mathrm{kg}$ ) and after weighing was determined the productivity ( $\mathrm{t}$ $\mathrm{ha}^{-1}$ ). For the determination of starch percentage, was collected of each parcel a sample of $5.0 \mathrm{~kg}$ of roots, using the hydrostatic scale method (Grossman \& Freitas, 1950). After the starch percentage determination, the results were converted to starch productivity $\left(\mathrm{t} \mathrm{ha}^{-1}\right)$.

The results of intoxication of cassava plants and weed control were graphically presented using the standard means error, while the root and starch productivity were submitted to variance analysis and the F test $(p>0.05)$ and to the means comparison test Scott-Knott ( $p>0.05)$.

\section{RESULTS AND DISCUSSION}

The plants intoxication caused by the herbicides is presented in Figure 2. It was observed that the isolated application of S-metolachlor (1.92 $\left.\mathrm{kg} \mathrm{ha}^{-1}\right)$ and clomazone $\left(1,25 \mathrm{~kg} \mathrm{ha}^{-1}\right)$, and the sequential application of sulfentrazone/clomazone and the tank mixture of clomazone+S-metolachlor $\left(1.25+1.92 \mathrm{~kg} \mathrm{ha}^{-1}\right)$, did not cause intoxication to cassava plants during all evaluations (Figure 2A). Scariot et al. (2013) and Biffe et al. (2010b) also observed that the treatments clomazone $\left(1.08 \mathrm{~kg} \mathrm{ha}^{-1}\right), \mathrm{S}$ metolachlor $\left(1.92 \mathrm{~kg} \mathrm{ha}^{-1}\right)$ and clomazone+S-metolachlor $\left(0.9+1.44 \mathrm{~kg} \mathrm{ha}^{-1}\right)$ did not cause intoxication to cassava plants 'Cascuda' and, 'Baianinha' and 'Fibra', respectively.

In the sequential applications clomazone/ [mosotrione+S-metolachlor] $\left(1.25 / 0.24+1.92 \mathrm{~kg} \mathrm{ha}^{-1}\right)$ and S-metolachlor/[mesotrione+clomazone] $(1.92 / 0.24+1.25 \mathrm{~kg}$ $\mathrm{ha}^{-1}$ ), it was observed intoxication of $41,3 \%$ and $30,0 \% 7$ days after the second application (7 DA2A), respectively. At 28 DA2A, no visual symptoms of intoxication were observed (Figure 2A). The observed symptoms were caused by the inhibitors of the carotenoids synthesis (clomazone and mesotrione), once the caused injuries are characteristics of this mechanism of action, because yellowing o whitening of all foliar limbo mostly in the young leaves from the plants apex, or in leaves from the medium third with yellowing of the edges followed by necrosis and crooked areas. However, cassava is tolerant to herbicides from the group of pigment synthesis inhibitors such as clomazone and mesotrione, because they do not affect productivity (Silveira et al., 2012; Costa et al., 2013a).

It was verified that for late applications, the mesotrione isolated caused $15.8 \%$ of intoxication at 7 DAA, however, the injuries disappeared at 28 DAA (Figure 2B). Similarly, Silveira et al. (2012) verified that the application of mesotrione $\left(0.216 \mathrm{~kg} \mathrm{ha}^{-1}\right)$, provided $18,8 \%$ intoxication of cassava 'Coqueiro', while Silva et al. (2012) observed intoxication of $2.5 \%$ caused by mesotrione $\left(0.144 \mathrm{~kg} \mathrm{ha}^{-1}\right)$ for cassava 'IAC-12, both results at 35 DAA. The differences in the results may be related to the differential tolerance of the varieties to the herbicide mesotrione, besides the used dose.

The tank mixtures with mesotrione provided a more severe intoxication than its application isolate. The mesotrione+S-metolachlor and the mesotrione+clomazone caused $37.0 \%$ and $30.5 \%$ intoxication at 7 DAA, respectively, while the isolate application resulted in only $15.75 \%$ of intoxication, being that at 28 DAA no injuries were observed to isolate application or mixture.

The weed control in the cassava crop after the herbicide application is shown in Figure 3.

Was verified that at $78 \mathrm{DAP}$, all herbicides presented control over the weed superior to $90 \%$ (Figure 3A). However, after this period the herbicides applied isolate showed a reduction in the control efficiency. The tank mixture of clomazone+S-metolachlor increased the residual effect in relation to the isolated applications for about 99 DAP.

At the end of the evaluation period, only the sequential applications of sulfentrazone/clomazone, clomazone/[mesotrione $+\mathrm{S}$-metolachlor] and of S-

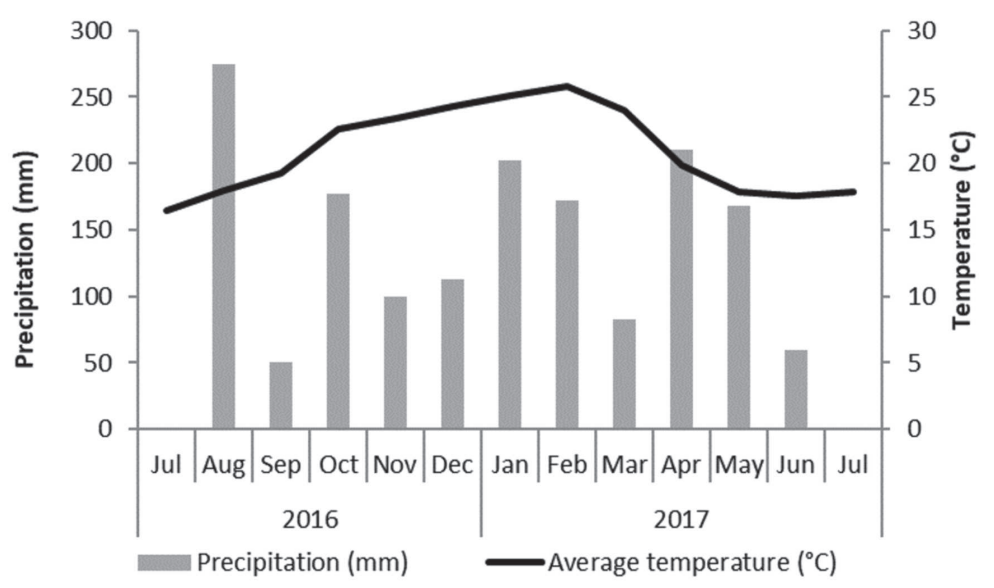

Figure 1: Meteorological data of rainfall $(\mathrm{mm})$ and temperature $\left({ }^{\circ} \mathrm{C}\right)$ obtained from the surface automatic meteorological observation station located nearby the experiment.

Rev. Ceres, Viçosa, v. 67, n.3, p. 240-246, may/jun, 2020 
metolachlor/[mesotrione+clomazone] showed weed control superior to $70 \%$.

Considering the application of sulfentrazone in preemergence and the sequential of clomazone in postemergence at 42 DA1A (92 DAP), there was a residual control effect of up to 98 DA1A (148 DAP), being superior to the crop CPPI, of 18 up to 100 days after planting.
Clomazone is preferably applied in pre-emergence and presents selectivity to cassava also in post-emergence applications, however the sulfentrazone is not recommended to post-emergence applications. Thus, the sequence of herbicide application must be observed before the applications to assure the selectivity.



Days after the $1^{\text {st }}$ application (DA1A)

Days after the $2^{\text {st }}$ application (DA2A)

$\rightarrow$ - clomazone

$\rightarrow$ S-metolachlor

$\multimap$ clomazone + S-metolachlor

$\multimap$ sulfentrazone/clomazone

$\rightarrow-$ clomazone/[mesotrione+S-metolachlor]

$\multimap$ S-metolachlor/[mesotrione+clomazone]

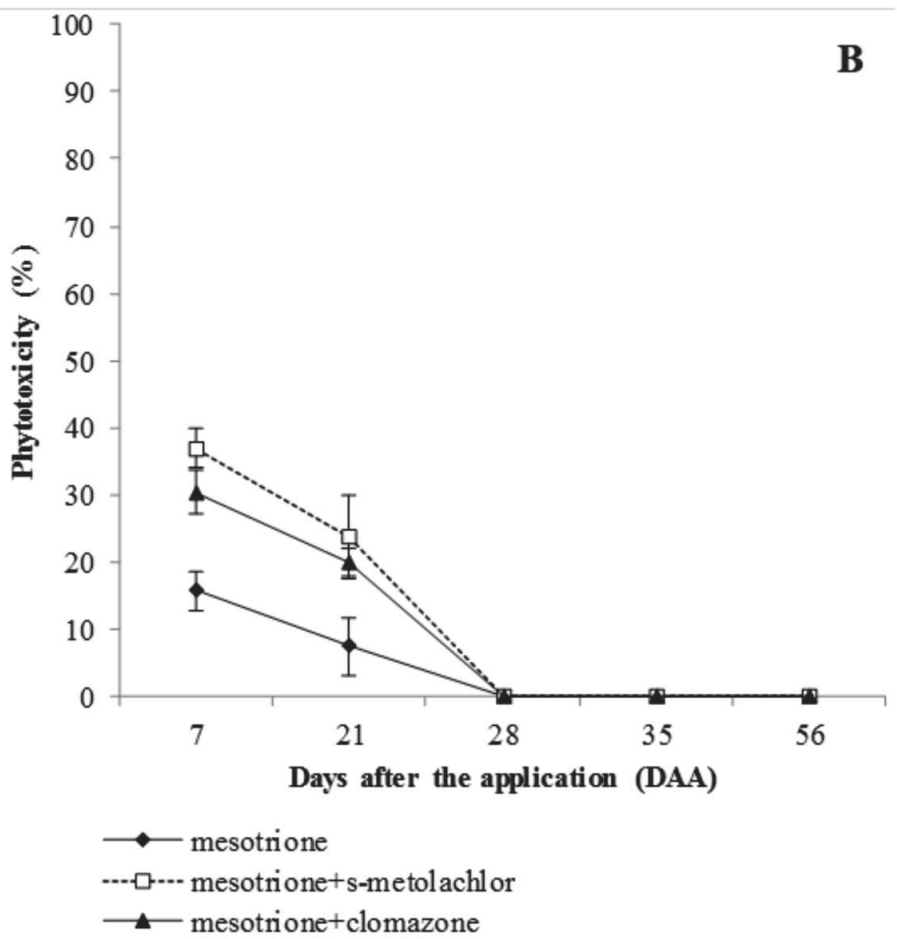

Figure 2: Percentage of intoxication of cassava plants 'Baianinha'. A) After the application of the herbicides isolate and in mixture $\left(1^{\text {st }}\right.$ application - 50 DAP) and sequential application ( $2^{\text {nd }}$ application - 92 DAP); B) After the herbicide application isolate and late at 92 DAP. Bars indicate the standard error of the means. 
The pre-emergence applications of clomazone and Smetolachlor showed satisfactory control to weed for only 28 DA1A, being that the sequential application of the tank mixtures of mesotrione $+\mathrm{S}$-metolachlor and of mesotrione+clomazone, respectively, contributed to the satisfactory restoration of weed control for a period superior to the CPPI of the crop.
In the same way, the late applications of tank mixtures mesotrione+S-metolachlor and of mesotrione+clomazone showed control superior to $70 \%$ until 148 DAP, while the isolate application of mesotrione promoted unsatisfactory control $(<70 \%)$ during all evaluation period (Figure 3B).

Mesotrione is recommended for post-emergence applications and have the same action mechanism as the
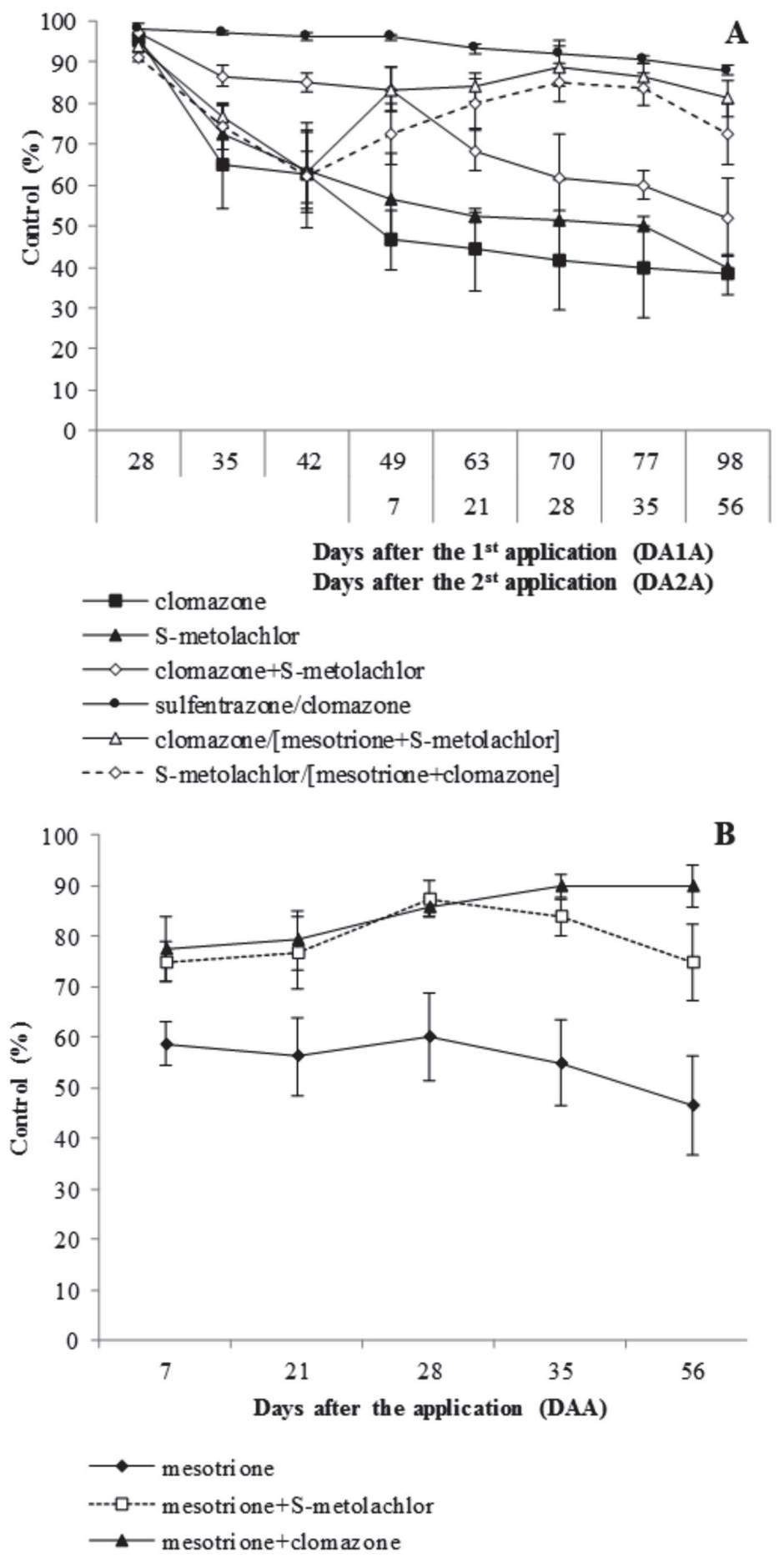

Figure 3: Notes of weed control (\%). A) After the isolated and mixture application of herbicides ( $1^{\text {st }}$ application - 50 DAP) and sequential application ( $2^{\text {nd }}$ application -92 DAP); B) After late isolate application at 92 DAP. Bars indicate the standard error of the means.

Rev. Ceres, Viçosa, v. 67, n.3, p. 240-246, may/jun, 2020 
clomazone. This explains the occurrence of similar injury symptoms caused by both herbicides in the cassava crop, as well as the fast recovery of the plants after applications.

It should also be noted that the use of mesotrione expands the management options of dicotyledon weed, once, nowadays there are only post-emergence herbicides registered for the control of grasses in the cassava crop. In the same way, the use of a pre-emergence (clomazone or S-metolachlor) in mixture with mesotrione in sequential late applications can increase the pre-emergence residual effect previously applied, besides controlling the escapes of emerged weed.

In general, these strategies for chemical control may help in the management of weed in a way to increase the residual control period and the action spectrum in the critical period of prevention of interference (CPPI), besides promoting the action mechanism rotation to avoid the selection of resistant biotypes. Galon et al. (2010) verified that $\mathrm{S}$-metolachlor (1.62 $\left.\mathrm{kg} \mathrm{ha}^{-1}\right)$ at $42 \mathrm{DAA}$ provided control of $20 \%$ of Brachiaria plantaginea while Raimondi et al. (2010) at 30 DAA, observed that the S-metolachlor (0.72 $\left.\mathrm{kg} \mathrm{ha}^{-1}\right)$ and clomazone $\left(1 \mathrm{~kg} \mathrm{ha}^{-1}\right)$ showed control superior to $80 \%$ and $60 \%$ respectively, of species Amaranthus hybridus, A. lividus, A. spinosus and A. viridis.

At Table 2 are presented the root productivity results and starch for the cassava crop 'Baianinha' after the herbicide application.

According to the results of root productivity it was verified the formation of three groups in the following order of decreasing average: Group A: harrowed control, mesotrione+S-metolachlor and clomazone/[mesotrione+Smetolachlor]; Group B: clomazone, mesotrione+clomazone, sulfentrazone/clomazone and mesotrione; Group C: control without harrow, S-metolachlor, S-metolachlor/ [mesotrione+clomazone] and clomazone+S-metolachlor. The Group A treatments were $20.8 \%$ and $8.4 \%$ superior to groups $\mathrm{B}$ and $\mathrm{C}$, respectively.

The herbicides belonging to Group A, may be considered highly selective to the harrowed control. It is emphasized that despite the intoxication caused by the sequential application of clomazone/[mesotrione+S-metolachlor] and the late mesotrione+S-metolachlor, these results demonstrate that cassava 'Baianinha' can metabolize the actives and maintain the productive potential of the intoxication.

As well as Costa et al. (2013b), which observed that the cassava 'Cascuda' recovered from the clomazone intoxication (1.08 $\left.\mathrm{kg} \mathrm{ha}^{-1}\right)$ and S-metolachlor (1.92 $\left.\mathrm{kg} \mathrm{ha}^{-1}\right)$ at 35 DAA, applied after the cassava pruning at the end of the first cycle. In a similar way, Costa et al. (2013a) noticed that cassava 'Cascuda' under mesotrione application in plants with an average height of $22.5 \mathrm{~cm}$ and 12 to 15 leaves, showed a recover right after 20 DAA when no mineral oil was used. Though, the $1.0 \%$ increase $\left(\mathrm{V} \mathrm{v}^{-1}\right)$ of mineral oil promoted visual damages of up to $51.3 \%$ in cassava at 12 DAA which disappeared after 43 DAA.

In the same way, considering the isolate application of clomazone with a commercial control, it can be inferred also that the herbicides belonging to Group B were selective, besides that the productivity was superior to the control without harrow.

The herbicides belonging to Group $\mathrm{C}$ were not selective to cassava 'Baianinha' due to productivity equal to that of the control without harrow, despite having a registered herbicide (S-metolachlor). This fact may be justified by the low efficiency in the weed control from the herbicides belonging to this group.

The results obtained for starch presented similar behavior to the obtained for roots productivity.

Table 2: Results of roots and starch productivity of cassava crop 'Baianinha' after the herbicide applications

\begin{tabular}{lcc}
\hline Treatments & Root productivity $\left(\mathbf{t ~ h a}^{-1}\right)$ & ${\text { Starch productivity }\left(\mathbf{t}^{-1} \mathbf{a}^{-1}\right)}$ \\
\hline Weed control & $35.00 \mathrm{a}$ & $8.98 \mathrm{a}$ \\
Weed-free control & $19.29 \mathrm{c}$ & $5.22 \mathrm{c}$ \\
clomazone & $27.15 \mathrm{~b}$ & $6.72 \mathrm{~b}$ \\
S-metolachlor & $22.14 \mathrm{c}$ & $5.51 \mathrm{c}$ \\
clomazone+S-metolachlor & $18.29 \mathrm{c}$ & $4.58 \mathrm{c}$ \\
sulfentrazone/clomazone & $25.97 \mathrm{~b}$ & $6.02 \mathrm{~b}$ \\
clomazone/[mesotrione+S-metolachlor] & $32.02 \mathrm{a}$ & $8.17 \mathrm{a}$ \\
S-metolachlor/[mesotrione+clomazone] & $21.15 \mathrm{c}$ & $5.33 \mathrm{c}$ \\
mesotrione & $24.53 \mathrm{~b}$ & $6.13 \mathrm{~b}$ \\
mesotrione+S-metolachlor & $31.50 \mathrm{a}$ & $7.92 \mathrm{a}$ \\
mesotrione+clomazone & $26.33 \mathrm{~b}$ & $6.53 \mathrm{~b}$ \\
\hline Treatment Medium Square & $117.34^{* *}$ & $7.62^{* *}$ \\
Block Medium Square & $6.55^{\mathrm{ns}}$ & $0.65^{\mathrm{ns}}$ \\
VC\% & 12.84 & 12.09 \\
\hline
\end{tabular}

$* * 1 \%$ and $* 5 \%$ significance by the $\mathrm{F}$ test. Means followed by the same letter in the column do not differ from each other by the Scott Knott test $(\mathrm{p}>0.05)$. 


\section{CONCLUSIONS}

Based on the data obtained, it is concluded that the mixture mesotrione+S-metolachlor and the sequential application of clomazone/[mesotrione+S-metolachlor] were selective to cassava 'Baianinha' and efficient in the weed control (over $80 \%$ up to 148 days after planting).

\section{ACKNOWLEDGEMENTS, FINANCIAL SUPPORT AND FULL DISCLOSURE}

The authors thank the National Council for Scientific and Technological Development (CNPq) for the financial support to this research project.

There is no conflict of interest between the authors in the publication of this work.

\section{REFERENCES}

ADAPAR - Agência de Defesa Agropecuária do Paraná (2018) Agrotóxicos do Paraná, 2018. Available at: http://www.adapar.pr.gov.br/modules/conteudo/conteudo.php? conteudo $=387$. Accessed on: June 13 ${ }^{\text {th }}, 2018$.

AGROFIT - Sistemas de Agrotóxicos Fitossanitários (2018) Consulta de produtos formulados, 2018. Available at: http:// agrofit.agricultura.gov.br/agrofit_cons/principal_agrofit_cons. Accessed on: June $27^{\text {th }}, 2018$.

Beckie HJ \& Harker KN (2017) Our top 10 herbicide-resistant weed management practices. Pest Management Science, 73:1045-1052.

Biffe DF, Constantin J, Oliveira Jr RS, Franchini LHM, Rios FA, Blainski E, Arantes JGZ, Alonso DG \& Cavalieri SD (2010a) Período de interferência de plantas daninhas em mandioca (Manihot esculenta) no noroeste do Paraná. Planta Daninha, 28:471-478.

Biffe DF, Constantin J, Oliveira Jr RS, Rios FA, Franchini LHM, Gemelli A, Arantes JGZ, Raimondi MA \& Blainski E (2010b) Avaliação de herbicidas para dois cultivares de mandioca. Planta Daninha, 28:807-816.

Costa NV, Pavan GC, Dourado RF, Costa ACPR \& Vasconcelos ES (2013a) Seletividade de herbicidas aplicados com óleo mineral na cultura da mandioca 'Cascuda'. Revista Brasileira de Herbicidas, 12:251-259.

Costa NV, Andrade DC, Sontag DA, Scariot CA \& Tsuzuki LH (2013b) Selectivity of clomazone and S-metolachlor applied after cassava pruning. Planta Daninha, 31:979-985.

Galon L, Tironi SP, Ferreira EA, Aspiazu I \& Pinto JJO (2010) Avaliação do método químico de controle de papuã (Brachiaria plantaginea) sobre a produtividade do milho. Pesquisa Agropecuária Tropical, 40:414-421.

Grossman J \& Freitas AC (1950) Determinação do teor de matéria seca pelo peso específico em raízes de mandioca. Revista Agronômica, 14:75-80.

IBGE - Instituto Brasileiro de Geografia e Estatística (2017) Levantamento Sistemático da produção agrícola. Rio de Janeiro, IBGE. $126 \mathrm{p}$.

Raimondi MA, Oliveira Jr RS, Constantin J, Biffe DF, Arantes JGZ, Franchini LH, Rios FA, Blainski E \& Osipe JB (2010) Atividade residual de herbicidas aplicados ao solo em relação ao controle de quatro espécies de Amaranthus. Planta Daninha, 28:1073-1085
Scariot CA, Costa NV, Bosquese EP, Andrade DC \& Sontag DA (2013) Seletividade e eficiência de herbicidas aplicados em préemergência na cultura da mandioca. Pesquisa Agropecuária Tropical, 43:300-307.

Silva FML, Abreu ML, Brachtvogel EL, Curcelli F, Gimenes MJ \& Lara ACC (2009) Moléculas de herbicidas seletivos à cultura da mandioca. Revista Trópica: Ciências Agrárias e Biológicas, 03:61-72.

Silva DV, Santos JB, Ferreira EA, Silva AA, França AC \& Sediyama T (2012) Manejo de plantas daninhas na cultura da mandioca. Planta Daninha, 30:901-910.

Silveira HM, Silva DV, Santos JB, Neto MDC, Ferreira EA, Carvalho FP, Silva AA \& Sediyama T (2012) Sensibilidade de cultivares de mandioca ao herbicida mesotrione. Revista Brasileira de Herbicidas, 11:24-31.

Silveira HM, Ferreira EA, Silva DV, Neto MDC, Carvalho FP, Santos JB \& Silva AA (2013) Características fisiológicas de cultivares de mandioca após aplicação do mesotrione. Planta Daninha, 31:403-409.

SBCPD - Sociedade Brasileira da Ciência das Plantas Daninhas (1995) Procedimentos para instalação, avaliação e análise de experimentos com herbicidas. Londrina, SBCPD 42p.

Zobiole LHS, Krenchinski FH, Moratelli G \& Costa NV (2018) Sumatran fleabane control using glyphosate in association with halauxifen-methyl formulations. Planta Daninha, 36:01-11.

Rev. Ceres, Viçosa, v. 67, n.3, p. 240-246, may/jun, 2020 